\title{
Lucien Bianco, Jacqueries et révolution dans la Chine
} du XXe siècle

Paris, Editions de La Martinière, 2005, 631 p.

\section{Alain Roux}

\section{OpenEdition}

\section{Journals}

Édition électronique

URL : http://journals.openedition.org/chinaperspectives/612

DOI : $10.4000 /$ chinaperspectives. 612

ISSN : 1996-4617

\section{Éditeur}

Centre d'étude français sur la Chine contemporaine

Édition imprimée

Date de publication : 1 avril 2006

ISSN : 2070-3449

\section{Référence électronique}

Alain Roux, «Lucien Bianco, Jacqueries et révolution dans la Chine du XXe siècle », China Perspectives [En ligne], 64 | march - april 2006, mis en ligne le 21 décembre 2006, consulté le 24 septembre 2020. URL : http://journals.openedition.org/chinaperspectives/612 ; DOI : https://doi.org/10.4000/ chinaperspectives.612

Ce document a été généré automatiquement le 24 septembre 2020

(c) All rights reserved 


\title{
Lucien Bianco, Jacqueries et révolution dans la Chine du XXe siècle
}

Paris, Editions de La Martinière, 2005, 631 p.

\author{
Alain Roux
}

\section{NOTE DE L'ÉDITEUR}

Translated from the French original by Philip Liddell

1 Patiently, passionately, Lucien Bianco has successfully concluded a mission that looked impossible: to explore the immensity of the Chinese peasantry and to describe the behaviour, over the half-century preceding the conquest of power by the Chinese Communist Party (CCP), of those 400 million people who cultivated in the traditional way 100 million hectares and eked out a miserable existence from it. From his very first article ("Les paysans et la révolution: Chine 1919-1969", followed by "Sociétés secrètes et autodéfense paysanne (1921-1933)", and by "Peasant movements"), Bianco threw doubt on a number of certainties relating to what was then considered the greatest peasant revolution in world history. His provocative hypotheses served to inspire dozens of innovative monographs, particularly in the United States. He succeeded eventually in winning access in the People's Republic to a wealth of local archive material and monographs (xianzhi and wenshi ziliao) made available only in the 1980s and 1990s. This was the basis for a book, published in 2001, the title of which reflected its originality: Peasant Without the Party: Grass-Roots Movements in Twentieth-Century China ${ }^{4}$. Its original analyses are partly taken up again in Bianco's new book. And he goes on to offer a much more orderly and systematic presentation of the results of his enquiries, thus crowning nearly four decades of research. This work of maturity is an overview, recalling in some respects the ambitions of former doctoral theses-but free of the stylistic ponderousness one associates with this kind of production. 
2 On the contrary, the writer chats informally ("me too") with his readers, replying here and there to objections that resurface elsewhere, as in a conversation, with no hint of that lofty tone that academics are expected to adopt. Thus, addressing anyone protesting against his decision to restrict his study to spontaneous peasant movements while excluding those whipped up from outside, principally by the communists, and further addressing anyone who might feel he was thus in danger of underestimating the peasants' fighting spirit, Bianco replies on page 221 that the communist interventions, by systematically politicising the peasant movements, exposed them to repression and drove as many peasants away from the struggle as it brought in. Similarly, Chapter 3 ("Numbers", pp. 104 to 129) is a model of intelligent evaluation of the statistical data he employs. Bianco's conclusions are half-way between some writers' excessive confidence in statistics and the systematic mistrust adopted by others. A "materialist" himself (page 17), Bianco is not one of those inverted dogmatists asserting culture before economics ; to him the economy is the basic motor of historical change. Nor, however, is he a positivist, paralysed by fear of advancing any conclusion not backed up by innumerable documents. This attitude saves him from adopting a moralist position or from being contemptuous of the peasants in the third part of the book (pp. 353-426), which deals with "peasant revolts and modernisation". It was tempting and partly justified to give the title "Peasants against Progress" to these three chapters. They describe the opposition to the banning of opium and to the authorities' legal measures to force Zhejiang peasants to purchase only the silkworm cocoons sold by official agencies, and not to use the often unhealthy eggs obtained on the farm. However, Bianco analyses the real motives behind this often violent unrest (pp. 366-369 and pp. 389-391). He does this, not by posing as an intellectual with an answer to everything from the comfort of his armchair, but by placing himself on a level with these poverty-stricken workers on the edge of starvation who find themselves deprived of a living wage or driven into new expenditure. One is reminded of the recent Bolivian election that brought Evo Morales, the Aymara Indian candidate of the "cocaleros", to the Bolivian presidency! Unceasingly, Bianco shares with us his scruples and the fragility of some of his hypotheses. He is ever-present, in the first person, in a book that often reads like an intellectual adventure. Despite the mass of facts, figures, tables, charts and graphs, despite the avalanche of notes, one can never tire of following him in his explorations. The insertion of translated or summarised texts in the course of the narrative, the richness of detail, the constant care to provide comparisons, all this combines to transport the reader into a world teeming with millions of obscure lives. One can breathe the acrid smells of the Chinese soil ; one is sucked into the mud of the paddy-fields; one sees the lined faces of these wretched people living from day to day, resigned for the most part, but occasionally rebellious. Moreover, the book's title might have been borrowed from another excellent recent work on the world of the former peasants, one often quoted by Bianco: La Rébellion française: mouvements populaires et conscience sociale (1661-1789), by Jean Nicolas ${ }^{5}$.

3 Indeed, Bianco presents to us the Chinese rebellion in a $90 \%$ rural China, taking as his starting-point the record of 3,579 conflicts that took place between 1900 and 1949, 70 per year. The figure roughly corresponds to the 8,500 conflicts, as described by Jean Nicolas, between 1661 and 1789, 65 per year, in a country twelve times less populated. And indeed, this reference is explicit in the title Bianco gives to his own book, using the old French term "jacqueries", or "peasant revolts" for events that took place several 
centuries later and thousands of miles away, but in which he recognises profound similarities.

4 In fact, the attitude of the Chinese peasants at the end of the Qing Dynasty and during the Republic often mirrors that of the French peasants of the Ancien Régime. When we leave China's coastal cities, travelling up the rivers and deep into the interior, are we not-even today-travelling backwards in time? Just like the rebels in the time of the Sun King, the Chinese peasants showed astonishing tolerance of the exploitation they were subjected to, and very little class consciousness. When they did rise up, they usually blamed the state and its agents. Thus, Bianco lists (in Table 5, p. 116) 1,140 uprisings against taxation and 800 against the administration, including 306 against conscription. Admittedly, in contrast with these 1,940 occurrences of peasants clashing with various forms of authority, he finds 1,395 conflicts within society itself; but of these, 802 were outbreaks of looting or subsistence riots and 380 were horizontal conflicts (xiedou, vendettas) leading to often bloody skirmishes between villages or clans. Only 154 recorded conflicts, that is, $4.3 \%$ of the total, arose out of resistance to farm tenancy (kangzu), whereas the tenant farmers (diannong) who made up the great majority of the peasants (each cultivating on average half a hectare) had to hand over nearly half (46\%) of their crop, in money or in kind, to the landowner-and on top of that deduction they had to pay taxes.

5 Peasant revolt tends to be conservative. It defends the status quo under threat from such-and-such an aggravation of taxation, surtaxes or some other exaction. And it aspires to the dream of a golden age far in the past. Furthermore, the catalogue of peasant struggles (Chapter 4) is very traditional. In particular, there is the "great feast" (chi dahu) in the invaded estates of such-and-such country squire, as described with delight by Mao Zedong in his famous report on peasant uprisings in the province of Hunan. Even when one seems to discern something resembling a strike, as with the jiaonong (jiaona nongju, the handing over of farm implements), this type of uprising (the peasants would abandon their tools in front of the administration offices to show that they were refusing to work in such conditions) existed well before the incipient workers' movement made this kind of resistance popular-so it was not a rural duplication. Let us consider the classification of popular uprisings proposed by Charles Tilly. He distinguishes between those he calls "competitive" where rivals dispute possession of limited resources, those he calls "reactive" where collective rights are defended against the state and its agents, and those he calls "proactive" where people seek to acquire new advantages and put forward political demands where necessary. This third category hardly existed. The conflicts before 1949 were mostly "reactive" and secondarily "competitive". People were not attacking the established order; rather, they were taking action against the disorder caused by injustices on the part of those in power.

6 Having carefully examined this spontaneous peasant resistance, the author looks in Part Four at the relations between peasants and the Revolution (pp. 423-494). Chapter 17, "Peasants and Communists in the Conquest of Power", puts forward a different interpretation of this event from that of Chalmers Johnson; writing in 1962, with his eyes fixed on the Vietnam War, Johnson saw in the victory of the communists in China the success of the nationalists, Tito-style, facing the Japanese aggressors. It is also different from that of all the historians who-taking their lead from Mark Selden (in 1971 and again in 1995)-have been insisting on social factors in the peasant 
mobilisation behind the communists. Bianco borrows for his own use (p. 439) an expression of Gregor Benton, for whom "it is weapons and not classes that made the Chinese revolution", while making it clear all the same that this victory would not have been possible if the intellectuals and the other professional revolutionaries who were leading the Communist Party had not been able to mobilise these victorious peasant armies. By presenting the revolution as a construction and not as a spontaneous uprising, Bianco supports Chen Yung-fa's demonstration in his book Making Revolution :

the Communist Movement in Eastern and Central China 1937-1945.

In his approach, Bianco relies on the results of the examination of the peasant world that he has carried out over the earlier chapters: the peasants' behaviour was particularist and defensive; their class consciousness was weak, but accompanied by the desire to protect their local community. Indeed, Mao Zedong complained in 1928 that "the masses are cold and reserved" towards the revolutionaries. Without having succeeded in completely changing that attitude, the communists did manage-with unintended help from the Japanese-to push the peasants into a real turnabout : they had to confront a political and social status quo that only recently they had been seeking to preserve. We know the proverb "the poor don't attack the rich; the people don't attack the mandarins (pin mo doufu, min mo dou guan)", to which one may add another proverb-though it seems at first to be contradictory: "It is the mandarins who force the people into rebellion (guan bi min fan)." The Communist Party had to act in such a way, despite the peasants' mistrust, that an occasional rebellion, due to the bad behaviour of someone representing a power otherwise accepted, should become an indestructible submission to a revolutionary party. This difficult alchemy, "hewing from the rough stone the foot soldiers of the revolution" was the work of a hard core of communist activists recruited first of all from the rural elite who had been educated in the cities and then rejected. Their youth was a more decisive factor in recruiting them than their social origin, despite assertions to the contrary from communist theoreticians. Once the Communist Party had succeeded locally in building up an effective administrative structure backed by credible armed forces, the peasants rallied to it in order to survive, in the face of terrorist and predatory raids by the Japanese. Without the latter, the CCP would probably never have succeeded.

When necessary, as during the winter of 1941, in Licheng in Shanxi, the communists used the peasant forces to maintain control over villages seeking freedom. During the civil war, from 1946 onwards, the vengeful spirit of the Guomindang, who wanted to punish all those who had accepted communist power, and the White Terror, which accompanied in the recaptured villages the victorious return of its armies until the summer of 1947 , combined in restoring to the communists their protective role. They strengthened it by redistributing to the poor peasants and the farm labourers the land seized from the landowners. Furthermore, the violence of the actions undertaken by peasants against the wealthy (when the communists gave them the opportunity to express it), which had appeared already during the brief Hailufeng Soviet between October 1927 and February 1928 (p. 453), reflects the sharpness of those social tensions in the villages concealed behind the Confucian parade of paternalist consensus (ganqing) : the communist mobilisation brought to light this latent dynamism. Thus, an unequal exchange was effected between the Communist Party and the peasantry: the peasants contributed money, work and young recruits in exchange for security and land. They still preserved a certain distance, as William Hinton shows in Fanshen, 
published in 1966, which describes the hesitations of the peasants in a Shanxi village that had fallen into communist control as early as autumn 1947. Without the communists, the peasants would have remained at the stage of mere revolt. Their revolutionary consciousness was built from outside. This interaction between the Communist Party and rural society changed both of them, but not completely : the CCP remained Leninist and determined to impose socialism at the instigation of a Partystate that seized for itself the monopoly of power, whereas the elements of continuity observed in the study of spontaneous uprisings among the peasantry were more powerful than the disruption to which peasants were subjected between 1947 and 1951 in the context of the communist victory and the agrarian reforms.

The 36 pages, only $13 \%$ of the whole book, that Bianco devotes to presenting the overt or covert resistance of the peasants to the communist government do not have, obviously, the same status as the 455 preceding pages. He seeks in these last two chapters to invite researchers to follow him in the approach he has taken so far, when conditions become favourable. He identifies tendencies in the form of hypotheses based on other people's books, except for a few points where he has himself been able to build up a dossier: the village vendettas (xiedou), for instance, or the anti-tax riots in Renshou (Sichuan) in 1993 (pp. 470-471). To others is left the task of studying on the ground the changes that sociologists or ethnologists may already observe, as does the collective work directed by Isabelle Thireau and Wang Hansheng, the results of which are presented in Disputes au village chinois, Formes du juste et recompositions locales des espaces normatifs. We may compare the results of this field study, focused on the countryside during the years following Deng Xiaoping's reforms, with those reached in the same writer's earlier work in collaboration with Hua Linshan, Enquête sociologique sur la Chine $1911-1949^{8}$. Bianco contributes an article, (Xiedou et équité) to Disputes au village. Rather surprisingly missing from these two books (and consequently from the article) is the excellent bibliography supplied in Bianco's book.

Concluding his preceding survey, in these few pages Bianco puts his hypotheses to the test of practical experience by examining the peasants' subsequent behaviour during the second half of the last century. He adds a reflection on the "weapons of the weak" (an expression borrowed from James Scott), ranging from slow or botched work to sabotage, which he sees rather as weak weapons, unlike Daniel Kelliher who in 1992 described them as the bases of "peasant power". Elizabeth Perry, in a 1985 article (published in the China Quarterly) on rural violence in socialist China, believed she could distinguish two types of behaviour among the peasants, one essentially "reactive" up to 1980 , and the other essentially "competitive" since the reforms. But Bianco favours the continuity of an essentially "reactive" resistance, and still not very "proactive", bearing in mind that the spectacular increase in this resistance, which has risen from a few thousand conflicts in the 1990s to 74,000 this year, is largely explained by the drop in the efficiency of social control, compared with what it was in Mao's time, and by less severe repression, and does not in any way reflect greater impoverishment among the peasants.

11 Lastly, Bianco reflects on present-day changes and on early indications, perhaps, of politicisation. But he seems content to sum up with the judgement that closes his book on page 493 : "The peasants are still not ready to take aim at the government . . . Neither will they act as a reserve force for the city dwellers, whom they envy and detest, and who despise them. City dwellers-and, in particular, intellectuals-are no 
more eager than the Party leadership for a democracy that would give majority rule to the peasants. This would continue to be the case for several decades to come, until a still more massive rural exodus may settle once and for all the migrants and their descendants in the cities".

In exact conformity with this pattern were the recent serious incidents in Guangdong province when peasants were thrown off their land with derisory compensation (and have still not been allowed back). Thus, what do we observe in the village of Dongzhou, in the sub-prefecture of Shanwei, where the police killed between three and twelve demonstrators and established something like a state of siege ? Essentially, a strong continuity with the uprisings of the last century: the demonstrators progressed from peaceful behaviour, burning incense and kowtowing to the representatives of authority, to extreme violence when no one would listen to them. Moreover, the authorities sent to prison the local deputy police chief who apparently ordered his men to open fire, while standing firm on the decisions that had prompted the demonstrations. We should remember that this was quite close to Honghai wan, formerly know as Bias Bay, a favoured haunt over decades past, of fearsome pirates. We hear that reinforcements for the demonstration came hurrying in from the surrounding area and especially from Lufeng. It would be hard not to think of those peasant unions of Haifeng and Lufeng organised by Peng Pai ; or of the terrible Soviet of Hailufeng where, during the winter of 1927-28, the forces of repression and the rebel peasants vied with each other in horrific acts of cruelty, to be duplicated during the Cultural Revolution. In this way one can understand a little better the nervousness of the forces of repression and the unwonted boldness of the 300 peasant activists who were defying them. Alternatively, one might rather pick out the new aspects of this conflict : the demonstrators sending digital photos to the Hong Kong newspapers, the presence of journalists assuming greater importance because the World Trade Organisation was about to meet in Hong Kong, and the protest against the construction of a coal-fired power station being accompanied by ecological considerations arising from the pollution of a nearby fishing lake. Only the future can reveal whether these peasant protests over the past year or two have ushered in a new era. And whether Bianco will have to revise his conclusion.

For the time being, Jacqueries et révolution helps us not only to understand the history of the Chinese peasants during the last century, but also to evaluate the present-day uprisings of the Chinese peasantry, confronted by globalisation and the contradictions of the harsh yet spectacular industrial revolution now in progress.

\section{NOTES}

1. Politique étrangère, 1968.

2. Jean Chesneaux (dir.), Mouvement populaires et sociétés secrètes en Chine aux XIXe et XXe siècles, Paris, Maspéro, 1970.

3. Cambridge History of China, Vol. 13, 1986, pp. 270-328. 
4. M.E. Sharpe, Armonk, N.Y.

5. Paris, Seuil, 2002.

6. Berkeley University Press, 1986.

7. Paris, Editions de la Maison des Sciences de l'Homme, 2001.

8. Paris, PUF, 1996. 